\title{
Educational leadership research, Twitter and the curation of followership
}

\author{
Scott $\operatorname{Eacott}^{1}{ }^{10}$
}

Received: 28 June 2020 / Accepted: 12 December 2020 / Published online: 2 January 2021

(c) The Author(s) 2021

\begin{abstract}
For an applied field, the role of research expertise is of considerable importance. With an increasing number of school leaders turning to social media for their professional learning-as part of a broader digital turn in knowledge generation, distribution, and consumption-the argument of this paper is that the notion of research expertise in educational leadership is shifting. Traditional modes of acquiring and sustaining research capital (e.g., publications, citations, research income) have been replaced by social presence, profile building, and the curation of followership. Building on work claiming there is a 'cult of the guru' in educational leadership, this paper draws on an appropriation of Hall's Kardashian index ( $K$-index) for 50 researchers, an analysis of Twitter user networks using NodelXL, and relational theorizing to investigate the ways in which research expertise is being mobilized / recast by educational leadership researchers on Twitter. Establishing an empirical foundation for ongoing dialogue and debate it is argued that the recasting of research expertise to those curating followership, and potentially divorced from research performance, is of timely significance for the ongoing credibility of the field both internally and within the broader academy.
\end{abstract}

Keywords Twitter $\cdot$ Kardashian-index $\cdot$ Social media $\cdot$ Cult of the guru $\cdot$ Relational $\cdot$ Auctor $\cdot$ Organizing activity $\cdot$ Spatiotemporal conditions $\cdot$ Followership $\cdot$ Attention

\section{Introduction}

Online platforms are changing the ways we think of expertise. With regulators and funders expecting greater public impact and influence from their investment (Schnitzler, Davies, Ross, \& Harris 2016; Watermeyer 2015), online activities are re-casting relations between research and expertise. The traditional 'publish or perish' approach to academia has been displaced by 'get visible or vanish' (Doyle \& Cuthill 2015). Social media provide the possibility of amplifying the voice of researchers beyond the academy (Bombaci et al. 2016; Pearce 2015; Thoma 2015) while also enhancing the prospects of traditional scholarly performance measures such as citations (Eysenbach 2011; Ortega 2017). With social media available to anyone with internet access, unlike traditional scholarly outputs which for the most part remain behind paywalls, (social) science has been

Scott Eacott

s.eacott@unsw.edu.au

1 University of New South Wales, Sydney, New South Wales, Australia opened up. However, the research capital once associated with professorial status and track record (e.g., publications, higher degree supervision, grant income) does not necessarily translate onto social media (Veletsianos \& Kimmons 2016) and there is the potential for those trading of academic titles to gain notoriety through brand management and selfpromotion (Cabrera \& Lloret 2017) rather than research and track record.

Educational leadership is a field particularly sensitive to such changes. It has been argued that the field suffers from a 'cult of the guru' (Eacott 2017) grounded in an 'attention economy' (van Krieken 2019) where perceived expertise is more likely to be linked to followership (e.g., the amount of followers) than traditional research expertise expressed through track record of publications and citations. Social media, in particular Twitter, has potentially amplified the cult of guru by creating new ways of building profile. Fortunately, the public nature of social media platforms (e.g., Twitter) and citation metrics (e.g., Google Scholar) makes it possible to empirically test how followership and networkbased activities are used to attract and sustain attention in educational leadership. Theoretically informed by the 
relational approach (Eacott 2018), this paper brings together previously disparate bodies of literature (educational leadership, social media studies, relational sociology, researcher development) to investigate the potential re-casting of research expertise through social media.

\section{Theoretical resources}

To achieve its aim of investigating the role of Twitter in contemporary conceptualizations of research expertise in educational leadership this project needed theoretical resources that did not default to privileging one form of expertise over another. Rather, it needed resources open to the possibility of recasting research expertise in educational leadership. To that end, this paper is theoretically informed by Eacott's (2018) relational approach. As an overarching methodological framework, it is built on five key intellectual moves. Figure 1 (below) brings these five methodological moves into conversation with research expertise in educational leadership.

Rather than a traditional academic paper structure (e.g., introduction, literature review, methodology, findings, discussion, conclusion), to retain fidelity with the relational approach, the five methodological moves serve as the analytical structure for the paper. This is achieved by breaking the five moves into three sections: (i) the underlying assumptions of what counts as 'expertise' [the explanatory gap]; (ii) how it plays out in practice [the empirical question]; and (iii) theorizing the re-casting of expertise in educational leadership [the contribution]. The first of these sections involves looking at the literatures of the field to locate how ideas of expertise are potentially changing. Empirically investigating how it plays out in practice draws on researchers' Google Scholar citations and Twitter networks data. Then, in proposing a relational alternative the paper goes beyond the frequent (although not exclusive) use of social theory in educational leadership that critiques to illuminates how some field members are mobilizing Twitter activity to curate followership to generate the perception of expertise.
To achieve the above the three key concepts of the relational approach are mobilized: organizing activity (a focus on the ongoing generation of the social world rather than separate knowable entities), auctor (meaning s/he who generates), and spatio-temporal conditions (blurring the boundaries of time and space). Shifting the focus from research expertise as an external stable and knowable entity that someone has to relations, the relational approach offers a means of composing theoretically inscribed descriptions of unfolding activity. The organizing activity of the field is how we come to understand 'expertise'. As auctors embedded and embodying of this organizing activity they are constantly making and re-making the field. The logic of the relational theory is that auctors generate spatio-temporal conditions through organizing activity. Theoretically and methodologically, this generative principle generates the possibility of engaging with the fluidity and constant flux of the social world without granting too much explanatory value to a particular platform, individual, or measure.

\section{Underlying assumptions of what counts as 'expertise'}

The struggle over expertise in educational administration and leadership has been an enduring one. In 1964 Walker (p. 12) noted "[I]n some quarters the necessity for any formal study of administration on the part of educators is seriously questioned." Many early graduate classes in the field primarily consisted of narratives from instructors who were experienced (and usually recently retired) school administrators (Baron \& Taylor 1969; Walker, Crane, \& Thomas 1973). Research, as in the systemic study of a phenomena, has not necessarily been a high priority area for educational administration and leadership professors (Hills 1965; Immegart 1990) and there is a relatively weak profile within the already weak quality profile of education research (Gorard 2005). Anderson and Jones (2000) argue that with the possible exception of the school effectiveness/school improvement literature, few research programs or theoretical advances in educational administration and leadership have

Fig. 1 The relational framing of the paper

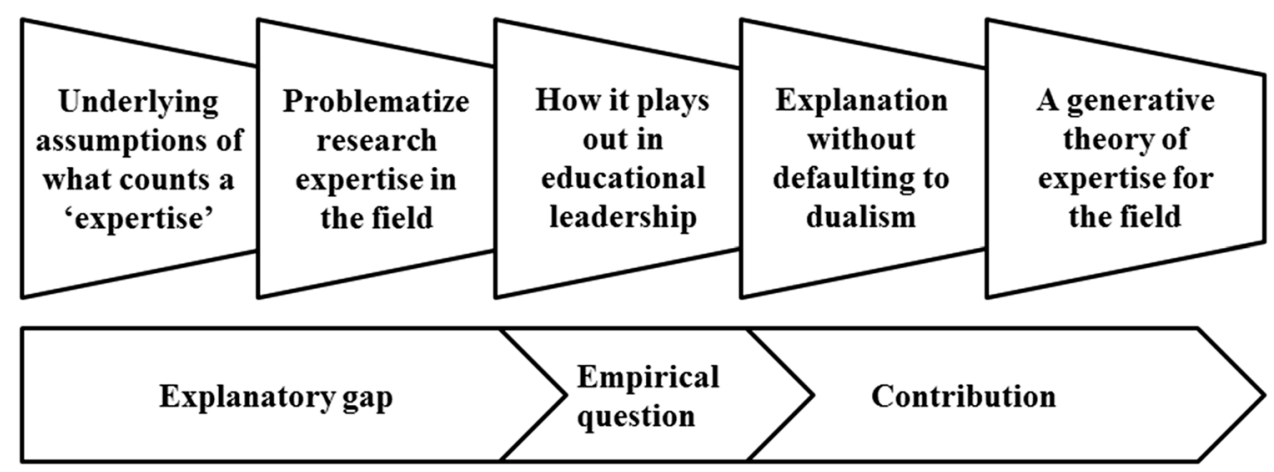


made a significant impact on practice. Attempts at improving the rigor and robustness of research in educational administration and leadership, such as the mid-twentieth century Theory Movement, have done little to alter the situation. Argyris and Schön (1974) argue, "the technology of rigorous research works best when it does not deal with real-time issues-for example, when scholars take years to study a decision that took hours to make" (p. 4). The pursuit of traditional research expertise and credibility may be at odds with achieving credibility with school administrators and leaders.

In contrast, knowledge translation, speaking directly to those 'in the field' through teaching, professional learning workshops and consultancies, has always been a key focus for educational administration and leadership researchers. With new knowledge constantly being generated (English 2006), school leaders as auctors are turning to new platforms to access research and expertise in real-time. Increasingly, school leaders are turning to social media-notably Twitter-for their professional learning and networking (Cho 2016; Jefferis \& Bisschoff 2017). Social media platforms are recasting the spatio-temporal conditions of educational leadership by generating a new avenue to reach audiences not necessarily well-served through traditional scholarly outlets and at a scale and timeframe not previously possible. For contemporary professors, social media presence and research activities are no-longer separate but deeply interwoven (Carrigan 2016). In doing so, social media is arguably challenging the norms of academic activity (Budge, Lemon, $\&$ McPherson 2016) and potentially what it means to have research expertise.

Social media platforms rely on algorithms to promote usage and interactivity. Unlike past broadcast media, contemporary social media are intended to be more interactional. Twitter provides a means of speaking directly to those in the field. Research expertise on social media is arguably less about scholarly track record and more concerned with how one's feed (list of Tweets) links with the work of schools and administrators. For the platforms' algorithms followership becomes integral, the more followers the greater the reach and potential influence (hence the label of 'influencer' to describe those with substantial followership). Although a problematic measure due to the possibility of gaming (e.g., buying followers, setting up multiple accounts and self-following), followership is the basis of the contemporary attention economy. Higher follower numbers translates into legitimation of the value of, or endorsement for, what is being said. The visibility of followership, where the number of followers is listed on profiles, encourages individuals to foster an audience to grant credibility to their work. This is central to the attention economy of the 'micro-celebrity' and 'insta-famous' (Marwick 2015). However, Waite (2016) warns "[o]ften, the substance of what these personalities have to offer is weak or lacking entirely and their primary positive attribute, the thing that recommends them, is their popularity or celebrity" (p. 127). He goes on to add "[w]e must scrutinize even the most popular of reformers, for the herd is easily swayed by celebrity and by the 'research says' academics" (p. 145). Despite some literature on 'academic rock stars' (Cho 2016), relatively little is known about how educational leadership researchers' Twitter followership and activity are related to traditional scholarly track record (e.g., publications and citations).

\section{How it plays out in practice}

Focusing on the role of Twitter activity is timely given increasing usage by educators and claims that the attention seeking economy of such platforms generates hierarchies (Marwick 2015) that may be divorced from traditional performance metrics (Veletsianos \& Kimmons 2016). In response to Eacott's (2017) "cult of the guru” paper, critics were quick to defend Hattie and his mega-analysis rather than engage with the claims around the rise (and rise) of gurus in educational leadership (see: Eacott 2019; Hattie 2017). While Hattie was the specific example nuanced in the paper, Eacott also names Michael Fullan, Andy Hargreaves, Alma Harris, and Yong Zhao among those popular on the international educational leadership keynote circuit (see also: Eacott 2020). To add further weight to this claim, Gunter and Mills (2017) identify Michael Fullan, Andy Hargreaves, Louise Stoll and David Hopkins among a group of researchers come consultants, and Thomson (2019) identifies Michael Fullan and Andy Hargreaves as "international consultants" (p. 104). There are consistent names identified who mobilize a level of research expertise, primarily through academic titles and university affiliation, but fulfil roles not necessarily valued in traditional scholarly circles.

The biographical work by Gunter and Mills (2017) demonstrates how increasingly the professor-researcherconsultant role is becoming more accepted within certain fields of education arguably built upon the assumption that one informant expresses as "you don't influence by doing normal academic work" (p. 44). The core argument of the cult of the guru paper was that the uncritical adoption of what is contemporarily popular is often based less on the rigor and robustness of knowledge claims and more on simple messages, slogans and the popularity of the speaker. This raises the prospect that some well-known figures in educational leadership might be well-known simply for being well-known, in pop culture terms, famous for being famous. There are means to test this claim. 


\section{1 (Social) Science Kardashians}

Built on a similar concern, Hall (2014) developed the Kardashian index or $K$-index. Its genesis being to "develop a metric that will clearly indicate if a scientist has an overblown public profile so that we can adjust our expectations of them accordingly" (p. 424). As Hall notes, we are all aware of keynote speakers who are invited for who they are rather than their work. To investigate the possibility of '(social) science Kardashians' in educational leadership this analysis draws on two groups: (i) academics with Google Scholar profiles linked to the keywords 'educational leadership', 'educational management' and/or 'educational administration' with one or more citations and Twitter profiles for greater than two years $(n=30)$; and (ii) keynote speakers (those identifying with academic titles and affiliations with the field of educational leadership) at significant educational leadership conferences (e.g., Australian Council for Educational Leaders; British Educational Leadership, Management and Administration Society; Commonwealth Council for Educational Administration and Management; and University Council for Educational Administration) with active Twitter profiles for greater than two years $(n=20)$. Table 1 displays the demographic profile (sex, current geographic location) for the sample of identified researchers.

As key measures, Hall (2014) takes a researcher's citation count as a proxy for 'scientific value' and Twitter followers as a proxy for 'celebrity' (p. 425). Although problematic measures, they serve as the two primary data points for the calculation of the $K$-index and can tell us something about the relations between traditional scholarly metrics and digital followership. Rather than a definitive statement, the $K$-index provides a beginning for an investigation.

Table 1 Demographic profile of identified researchers

\begin{tabular}{llll}
\hline Demographic & Group 1 & Group 2 & Total \\
\hline Sex & & & \\
Female & 13 & 10 & 23 \\
Male & 17 & 10 & 27 \\
Total & 30 & 20 & 50 \\
Country & & & \\
USA & 10 & 7 & 17 \\
Australia & 6 & 5 & 11 \\
UK & 5 & 5 & 10 \\
Canada & 4 & 2 & 6 \\
Germany & 1 & 1 & 2 \\
Turkey & 2 & 0 & 2 \\
New Zealand & 1 & 0 & 1 \\
Finland & 1 & 0 & 50 \\
Total & 30 & 20 & \\
\hline
\end{tabular}

After generating the followership and citation data for the identified researchers, an initial step was to establish a trend line for the data. This enables calculation of an expected followership based on citations relative to the field. Where $F$ is the number of Twitter followers and $C$ is the number of citations. Consistent with Hall, there was a positive correlation between followers and citations $(r=0.58, p=\leq 0.01)$, and it can be expressed as Eq. 1:

$F=0.4244 C+2730$

With a trend line established, it was then possible to calculate a typical number of followers and the $K$-index-which can be expressed as Eq. 2:

$K-$ index $=\frac{F_{(a)}}{F_{(c)}}$

where $F_{(a)}$ is the actual number of Twitter followers and $F_{(c)}$ is the number of followers a researcher could be expected to have given their citation count. Hall (2014) argues that a high $K$-index should serve as a warning to the community that a researcher may have built their profile on something other than research engaged with by peers. Although citation patterns differ across the social and natural sciences (e.g., Bastow, Dunleavy, \& Tinkler, 2014), the use of Google Scholar (as opposed to SCOPUS or Web of Science) means that far greater grey literatures are included and gives a more synoptic overview of work being picked up in an applied field. As noted previously though, calculating the $K$-index is only the first stage as identifying outliers, particular those with high $K$-index is important for the aim of this paper.

Although it is common practice to use the mean $(\overline{\mathrm{x}}=0.98)$ and three times the standard deviation $(\sigma=2.53$, S.E. $=0.36)$ to identify outliers (Howell, 1988), to counter for outlier effects in a non-normal distribution, Leys and colleagues (2013) argue that the median $(\tilde{\mathrm{x}}=0.24)$ and 'median absolute deviation' (MAD $=0.19)$ are a more robust measures of dispersion. They strongly recommend the median plus or minus 2.5 times the MAD are used to detect outliers. Adopting the proposal of Leys and colleagues, a $K$-index higher than or equal to 0.71 can be considered a '(social) science Kardashian' in the dataset. Across the sample, there are 12 researchers (24\% of sample, Group $14 / 30$, Group 2 8/20) who meet that threshold, constituted by 8 males / 4 females, and with current geographic locations of USA $(n=5)$, Australia $(n=3)$, Canada $(n=3)$, and the UK $(n=1)$-see Table 2. There are many reasons for why someone may have many more followers than might be expected and for that reason it is important to not make too much of the $K$-index. At the same time, that is insufficient reason to dismiss the existence of such a group and not further investigate for what it might tell us about the field. 
Table 2 High $K$-index researchers in educational administration and leadership

\begin{tabular}{llrlr}
\hline Group & Researcher & Followers & Citations & $K$-index \\
\hline 1 & $\mathrm{R}_{1}$ & 53,200 & 1,390 & 15.96 \\
& $\mathrm{R}_{2}$ & 3,226 & 228 & 1.14 \\
& $\mathrm{R}_{3}$ & 2,531 & 712 & 0.84 \\
& $\mathrm{R}_{4}$ & 2,532 & 773 & 0.83 \\
& $\mathrm{R}_{31}$ & 41,877 & 6,022 & 7.92 \\
& $\mathrm{R}_{32}$ & 12,396 & 302 & 4.34 \\
& $\mathrm{R}_{33}$ & 7,877 & 723 & 2.59 \\
& $\mathrm{R}_{34}$ & 14,086 & 7,252 & 2.43 \\
& $\mathrm{R}_{35}$ & 4,633 & 836 & 1.50 \\
& $\mathrm{R}_{36}$ & 3,703 & 1,203 & 1.14 \\
& $\mathrm{R}_{37}$ & 30,032 & 57,362 & 1.11 \\
& $\mathrm{R}_{38}$ & 43,828 & 88,353 & 1.09 \\
\hline
\end{tabular}

The higher percentage of social science Kardashians among the keynote group (Group 2) is not surprising. However, this does not mean it is without implications. For a country like Australia where there is no formalized requirement for post-graduate study in educational leadership, if the only time educators working in the field come into contact with researchers is through professional learning (e.g., conferences, professional associations) and increasingly social media, the generation of what it means to offer researchbased expertise is arguably reduced to those attracting attention. A secondary matter is how this attention can be mobilized by others to sustain and further legitimize expertise, something considerably expanded through proliferation of social media. In working with the data generated for the $K$-index analysis, a matter that warranted further attention was how Twitter based networks were being used to associate (through tagging others in tweets, particularly other high $K$-index individuals) rather than interact.

\subsection{Tagging relations}

The notion of 'tagging relations' takes from the wellrehearsed definition of a community as a network of researchers, but one that share significantly more links with each other than they do outside of this community. On Twitter, a 'tagging relation' can be considered a group of researchers that 'mention' each other disproportionately more than they do others who work in the same area. Not necessarily an interaction or reciprocal exchange, a mention can be a simple act of association. For educational leadership research, in what could arguably be described as the Matthew effect (Merton, 1968), the preferential attachment provided through these tagging networks raises the possibility for individuals to receive many more links and invitations through cumulative advantage (e.g., being linked to, and endorsed by) rather than explicit research expertise. Overtime certain auctors at the margins of these networks assume greater status-achieved through affiliation-much like how work has demonstrated this in relation to co-authorship and citation cartels (e.g., Fister, Fister, \& Perc, 2016; Perc, 2014).

To test the idea of a Twitter tagging relations, the same sample of educational leadership researchers identified for the $K$-index investigation $(\mathrm{N}=50)$ were subjected to analysis of Twitter activity using the NodeXL (version 1.0.1.398) add-on for Microsoft Excel developed by the Social Media Research Foundation (smrfoundation.org). A Twitter Users Network was extracted based on a 'basic network' showing tweets, mentions, and replies utilizing the default option of 3200 tweets per user. The final extracted dataset included 80,255 data points constituted by 68,876 tweets, 10,514 mentions and 865 replies. Table 3 displays the overall statistics for Twitter activity among the sample.

There were no statistically significant differences between Group 1 and Group 2 across tweets $(t=0.59, p=0.55)$, mentions $(t=1.08, p=0.30)$, or replies $(t=1.63, p=0.05)$. Of the three forms of posting activity, replies were very low across the sample. At only 1\%, there is a very low level of dialogue and debate among the sample. Only two researchers had more than 1000 posts and higher than $3 \%$ replies $\left(\mathrm{R}_{3} 5 \%\right.$ and $\mathrm{R}_{38} 3 \%$ ), with the mean across the sample $2 \%$. Demonstrating broadcasting as the orthodoxy, tweets represent $85 \%$ of activity. Building from the $K$-index analysis, of particular interest is the role of mentions as an activity in an attention economy-both who is tagged and by whom. Mentions constituted 13\% of the activity. Figure 2 displays the number of mentions for researchers in the sample from highest (1389) to lowest (0). To provide some relations to the previous $K$-index analysis, those identified as high $K$-index researchers are highlighted in darker grey. The mean for the sample is $210(\sigma=351.65, \mathrm{SE}=50.24)$ and the median 54 $(\mathrm{MAD}=50.00)$.

It is not necessarily the high $K$-index researchers who secure the greatest number of mentions. There are nine researchers who stand out as attracting a great proportion of the tags among the sample (7,969 mentions, 76\%), five of the social science Kardashians previously identified $\left(\mathrm{R}_{31}\right.$, $\mathrm{R}_{33}, \mathrm{R}_{34}, \mathrm{R}_{35}$, and $\left.\mathrm{R}_{38}\right)$ and four additions: $\mathrm{R}_{5}(K=0.66)$, $\mathrm{R}_{40}(K=0.54), \mathrm{R}_{42}(K=0.24)$, and $\mathrm{R}_{44}(K=0.23)$. The nine is constituted by two clusters with the four most mentioned researchers attracting $47 \%(n=4,947)$, and then the next five attracting 3022 or $29 \%$ of all the mentions. What is of greatest interest for the argument of this paper is who is getting mentioned and by whom. To investigate this matter, Table 4 shows a crosstab of the nine most mentioned and an 'other' (meaning those outside the nine) column to highlight the tagging relations. Two researchers $\left(\mathrm{R}_{42}\right.$ and $\left.\mathrm{R}_{44}\right)$ have mention networks substantially beyond the group, and one 
Table 3 Twitter activity of educational leadership researchers

\begin{tabular}{|c|c|c|c|c|c|c|}
\hline & \multicolumn{4}{|c|}{ Measure statistics } & \multicolumn{2}{|c|}{ Percent of distribution } \\
\hline & $\mathrm{N}$ & $\bar{x}$ & $\sigma$ & S.E & $\bar{x}$ & $\sigma$ \\
\hline \multicolumn{7}{|l|}{ Group 1} \\
\hline Tweets & 38,840 & 1439 & 1188 & 229 & 86.36 & 17.74 \\
\hline Mentions & 3233 & 120 & 220 & 42 & 10.93 & 14.94 \\
\hline Replies & 587 & 22 & 31 & 6 & 2.71 & 4.93 \\
\hline Total & 42,600 & 1580 & 1303 & 251 & & \\
\hline \multicolumn{7}{|l|}{ Group 2} \\
\hline Tweets & 30,036 & 1767 & 1132 & 275 & 83.17 & 16.71 \\
\hline Mentions & 7281 & 428 & 529 & 128 & 16.10 & 16.39 \\
\hline Replies & 278 & 16 & 16 & 4 & 0.73 & 0.92 \\
\hline Total & 37,595 & 2211 & 1374 & 333 & & \\
\hline \multicolumn{7}{|l|}{ Population } \\
\hline Tweets & 68,876 & 1565 & 1151 & 176 & 85.13 & 17.03 \\
\hline Mentions & 10,514 & 239 & 391 & 60 & 12.93 & 15.36 \\
\hline Replies & 865 & 20 & 26 & 4 & 1.94 & 3.95 \\
\hline Total & 80,255 & 1824 & 1336 & 204 & & \\
\hline
\end{tabular}

Fig. 2 The number of 'mentions' for the identified researchers. Legend: Black High K-Index Grey Rest of population

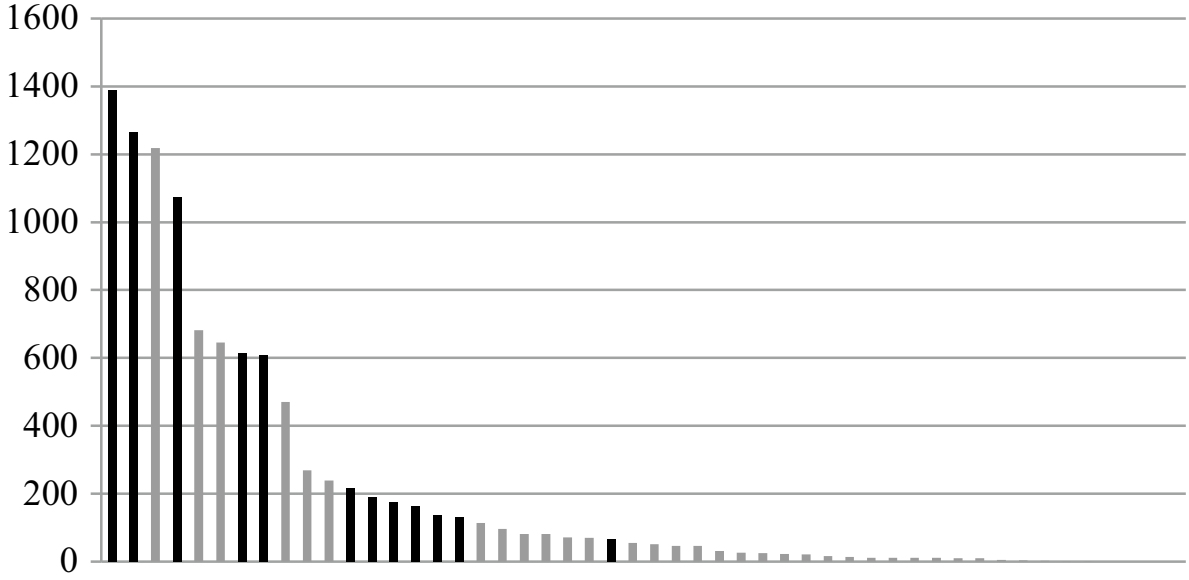

Legend: Black High K-Index Grey Rest of population researcher has the majority of mentions from a single other member ( $\mathrm{R}_{5}-\mathrm{R}_{40}$ but not necessarily reciprocated). In a similar situation, $R_{34}$ has an inflated 'other' score due to another single user's $\left(\mathrm{R}_{4}\right.$, a previously identified social science Kardashian) 385 tags or $59 \%$ of the other score. Removing this would drop $\mathrm{R}_{34}$ 's other score to $12 \%$

Removing the two researchers $\left(\mathrm{R}_{42}\right.$ and $\left.\mathrm{R}_{44}\right)$ who have mention networks beyond the group, leaves seven researcher who represents $65 \%$ of all 'mentions' in the sample, or 6,817 of the 10,514 . Significantly, the seven researchers are responsible for $77 \%(5,267 / 6,817)$ of these mentions. In other words, seven out of the 50 researchers $(14 \%)$ in the sample contribute $50 \%$ of the total mentions exclusively among themselves. These tagging relations meet the definition of a community of networked researchers who share significantly more mentions with each other than they do outside of the group. Based on the data, the seven give $87 \%$ $(5,267)$ of their mentions to one another compared to only 776 mentions (13\%) to 14 other researchers.

\section{Theorizing the re-casting of expertise}

The disproportionate mentioning among the seven cannot be easily explained away through enduring struggles of theory and practice or quality science communication. Even the concept of homophily, meaning that contact between similar people occurs at a higher rate than among dissimilar people (e.g., Daly, 2010), cannot capture the nuances of such relations and what is at stake for the field as it assumes a neutrality among relations. 
Table 4 Cross-tab of the nine most mentioned researchers

\begin{tabular}{|c|c|c|c|c|c|c|c|c|c|c|}
\hline \multirow[t]{2}{*}{$\begin{array}{l}\text { Researcher/men- } \\
\text { tions/taggers }\end{array}$} & \multicolumn{10}{|c|}{$\begin{array}{l}\text { Who is doing the tagging } \\
\text { (number and percentage of distribution) }\end{array}$} \\
\hline & $\mathrm{R}_{5}$ & $\mathrm{R}_{31}$ & $\mathrm{R}_{33}$ & $\mathrm{R}_{34}$ & $\mathrm{R}_{35}$ & $\mathrm{R}_{38}$ & $\mathrm{R}_{40}$ & $\mathrm{R}_{42}$ & $\mathrm{R}_{44}$ & Other \\
\hline $\begin{array}{l}\mathrm{R}_{5} \\
n=646 \\
19 \text { taggers }\end{array}$ & - & $\begin{array}{l}4 \\
(0.62)\end{array}$ & $\begin{array}{l}0 \\
(0.00)\end{array}$ & $\begin{array}{l}35 \\
(5.42)\end{array}$ & $\begin{array}{l}9 \\
(1.39)\end{array}$ & $\begin{array}{l}5 \\
(0.77)\end{array}$ & $\begin{array}{l}436 \\
(67.49)\end{array}$ & $\begin{array}{l}0 \\
(0.00)\end{array}$ & $\begin{array}{l}0 \\
(0.00)\end{array}$ & $\begin{array}{l}157 \\
(24.30)\end{array}$ \\
\hline $\begin{array}{l}\mathrm{R}_{31} \\
n=1074 \\
19 \text { taggers }\end{array}$ & $\begin{array}{l}62 \\
(5.77)\end{array}$ & - & $\begin{array}{l}7 \\
(0.65)\end{array}$ & $\begin{array}{l}45 \\
(4.19)\end{array}$ & $\begin{array}{l}492 \\
(45.81)\end{array}$ & $\begin{array}{l}123 \\
(11.45)\end{array}$ & $\begin{array}{l}187 \\
(17.41)\end{array}$ & $\begin{array}{l}0 \\
(0.00)\end{array}$ & $\begin{array}{l}0 \\
(0.00)\end{array}$ & $\begin{array}{l}158 \\
(14.71)\end{array}$ \\
\hline $\begin{array}{l}\mathrm{R}_{33} \\
n=608 \\
16 \text { taggers }\end{array}$ & $\begin{array}{l}25 \\
(4.11)\end{array}$ & $\begin{array}{l}47 \\
(7.73)\end{array}$ & - & $\begin{array}{l}94 \\
(15.46)\end{array}$ & $\begin{array}{l}290 \\
(47.70)\end{array}$ & $\begin{array}{l}23 \\
(3.78)\end{array}$ & $\begin{array}{l}54 \\
(8.88)\end{array}$ & $\begin{array}{l}0 \\
(0.00)\end{array}$ & $\begin{array}{l}0 \\
(0.00)\end{array}$ & $\begin{array}{l}75 \\
(12.34)\end{array}$ \\
\hline $\begin{array}{l}\mathrm{R}_{34} \\
n=1266 \\
19 \text { taggers }\end{array}$ & $\begin{array}{l}97 \\
(7.66)\end{array}$ & $\begin{array}{l}79 \\
(6.24)\end{array}$ & $\begin{array}{l}6 \\
(0.47)\end{array}$ & - & $\begin{array}{l}313 \\
(24.72)\end{array}$ & $\begin{array}{l}22 \\
(1.74)\end{array}$ & $\begin{array}{l}215 \\
(16.98)\end{array}$ & $\begin{array}{l}0 \\
(0.00)\end{array}$ & $\begin{array}{l}0 \\
(0.00)\end{array}$ & $\begin{array}{l}534 \\
(42.18)\end{array}$ \\
\hline $\begin{array}{l}\mathrm{R}_{35} \\
n=1389 \\
21 \text { taggers }\end{array}$ & $\begin{array}{l}82 \\
(5.90)\end{array}$ & $\begin{array}{l}295 \\
(21.24)\end{array}$ & $\begin{array}{l}18 \\
(1.30)\end{array}$ & $\begin{array}{l}205 \\
(14.76)\end{array}$ & - & $\begin{array}{l}303 \\
(21.81)\end{array}$ & $\begin{array}{l}274 \\
(19.73)\end{array}$ & $\begin{array}{l}0 \\
(0.00)\end{array}$ & $\begin{array}{l}0 \\
(0.00)\end{array}$ & $\begin{array}{l}212 \\
(15.26)\end{array}$ \\
\hline $\begin{array}{l}\mathrm{R}_{38} \\
n=616 \\
19 \text { taggers }\end{array}$ & $\begin{array}{l}42 \\
(6.82)\end{array}$ & $\begin{array}{l}54 \\
(8.77)\end{array}$ & $\begin{array}{l}5 \\
(0.81)\end{array}$ & $\begin{array}{l}22 \\
(3.57)\end{array}$ & $\begin{array}{l}351 \\
(56.98)\end{array}$ & - & $\begin{array}{l}72 \\
(11.69)\end{array}$ & $\begin{array}{l}0 \\
(0.00)\end{array}$ & $\begin{array}{l}0 \\
(0.00)\end{array}$ & $\begin{array}{l}70 \\
(11.36)\end{array}$ \\
\hline $\begin{array}{l}\mathrm{R}_{40} \\
n=1218 \\
23 \text { taggers }\end{array}$ & $\begin{array}{l}538 \\
(44.17)\end{array}$ & $\begin{array}{l}26 \\
(2.13)\end{array}$ & $\begin{array}{l}1 \\
(0.08)\end{array}$ & $\begin{array}{l}82 \\
(6.73)\end{array}$ & $\begin{array}{l}196 \\
(16.09)\end{array}$ & $\begin{array}{l}31 \\
(2.55)\end{array}$ & - & $\begin{array}{l}0 \\
(0.00)\end{array}$ & $\begin{array}{l}0 \\
(0.00)\end{array}$ & $\begin{array}{l}343 \\
(28.16)\end{array}$ \\
\hline $\begin{array}{l}\mathrm{R}_{42} \\
n=470 \\
13 \text { taggers }\end{array}$ & $\begin{array}{l}0 \\
(0.00)\end{array}$ & $\begin{array}{l}0 \\
(0.00)\end{array}$ & $\begin{array}{l}0 \\
(0.00)\end{array}$ & $\begin{array}{l}0 \\
(0.00)\end{array}$ & $\begin{array}{l}0 \\
(0.00)\end{array}$ & $\begin{array}{l}0 \\
(0.00)\end{array}$ & $\begin{array}{l}0 \\
(0.00)\end{array}$ & - & $\begin{array}{l}410 \\
(87.23)\end{array}$ & $\begin{array}{l}60 \\
(12.77)\end{array}$ \\
\hline $\begin{array}{l}\mathrm{R}_{44} \\
n=682 \\
21 \text { taggers }\end{array}$ & $\begin{array}{l}0 \\
(0.00)\end{array}$ & $\begin{array}{l}0 \\
(0.00)\end{array}$ & $\begin{array}{l}0 \\
(0.00)\end{array}$ & $\begin{array}{l}0 \\
(0.00)\end{array}$ & $\begin{array}{l}0 \\
(0.00)\end{array}$ & $\begin{array}{l}0 \\
(0.00)\end{array}$ & $\begin{array}{l}0 \\
(0.00)\end{array}$ & $\begin{array}{l}574 \\
(84.16)\end{array}$ & - & $\begin{array}{l}108 \\
(15.84)\end{array}$ \\
\hline Other Tagged \% & $\begin{array}{l}168 \\
6 \text { names } \\
(16.57)\end{array}$ & $\begin{array}{l}101 \\
3 \text { names } \\
(16.67)\end{array}$ & $\begin{array}{l}2 \\
2 \text { names } \\
(5.13)\end{array}$ & $\begin{array}{l}141 \\
6 \text { names } \\
(22.60)\end{array}$ & $\begin{array}{l}101 \\
9 \text { names } \\
(5.76)\end{array}$ & $\begin{array}{l}4 \\
2 \text { names } \\
(0.78)\end{array}$ & $\begin{array}{l}259 \\
8 \text { names } \\
(17.30)\end{array}$ & $\begin{array}{l}205 \\
8 \text { names } \\
(26.32)\end{array}$ & $\begin{array}{l}295 \\
17 \text { names } \\
(41.84)\end{array}$ & - \\
\hline
\end{tabular}

The visibility of metrics (followers, retweets, likes) grants ontological status to being a person of influence. Those who are able to credibly enact expertise to curate followership grant legitimacy to themselves and others through activities that sustain a social order. Field members are not external to such relations and instead auctors generate them through the giving, or not, of attention/followership. The accessibility of high follower individuals creates a belief in Twitter as a means of democratizing the field. Research and researchers are no longer only available to those working or studying in universities or research institutes, they are now accessible to all with internet access.

Working from the germinal work of Horton and Wohl (1956), the relationship between high profile researchers and knowledge consumers is one of the central attributes of mass information consumption. The low level of interaction through replies is not dissimilar to how mainstream celebrities approach social media. However, Twitter's followership functionality has helped create the illusion of a faceto-face relationship. A follower (e.g., school administrator or teacher) can like, reply, or retweet a post from a big name in the field as though s/he is a personal acquaintance. These parasocial relations (Giles, 2002) further legitimize those with large followership and high mentions. Therefore, while research expertise in educational leadership was once something an individual had (e.g., through publications, citations, grants, experience), the proliferation of social media and curating of profiles and networks means that research expertise is now something one does. It is not tied to track record but instead based on the curation of followership.

The digital turn in accessibility, not only of research but researchers, establishes the conditions where one can accrue status through curating a tweet (e.g., message, quote, question, or claim) that attracts attention. The more attention granted by followers through likes, replies, and retweets, the greater legitimacy is granted to both the message and the messenger. Unlike traditional scholarly outlets which value originality and contribution in relation to existing knowledges, the value of this Twitter message is how new it is to the audience and its contribution to their work. This 
decentres the messenger and recasts the significance of the audience/followership. It is also distinct from peer review where a researcher is expected to locate their work in the intellectual traditions and history of dialogue and debate in the field. What becomes of greater importance in the attention economy of social media is new-ness for the audience. It enables a high profile individual to state something (e.g., equity is a problem for school outcomes) as though it is a new insight and that such an issue has not been addressed by researchers for many years. The mentioning of others and particularly other high profile experts (a deliberate act), gives added legitimacy to such claims with new audiences ever increasing the perceived expertise. In relational terms, field members (as auctors) are generating spatio-temporal conditions through attention giving activities. These activities are based on assumptions (organizing activity) regarding who has expertise.

\section{Conclusion}

With limited research to date, we are distant from a full appreciation and understanding of how the digital turn in contemporary knowledge generation is shifting notions of expertise in educational leadership and its implications for policy and practice. The data presented and the argument crafted in this paper has highlighted a potential re-casting of research expertise in the field through the curation of followership. Profile building is an act of curation, a discursive activity of generating an image of your contribution, building an audience, and advancing one's position through a coalition of similar individuals. Twitter activity is granted ontological status through aggregation. The more retweets, likes, engagement, the more activity is emphasized in the interface and its significance is ensured by the algorithms that select tweets for extra exposure based on popularity. Therefore, mentioning others with large followership attracts additional attention. For the field, Twitter activity, or more specifically presence, is conflated with expertise. In an attention economy, having a relatively large followership (compared to other field members) becomes a means of exercising influence and shaping the forthcoming direction of the field. The approach taken in this paper has enabled us to gain analytical purchase in terms of opening up understandings of research expertise to scrutiny. Twitter activity is not politically neutral and simplistic assumptions that highly mentioned research/ers are of value is misrecognition. For a field that has always grappled with the role of expertise, what remains to be seen is whether the recasting of research expertise through the digital turn is just the latest iteration of an enduring issue or the final curtain call for attempts to sustain traditional academic scholarship in an applied field. Only time will tell.

\section{Compliance with ethical standards}

Conflict of interest statement On behalf of all authors, the corresponding author states that there is no conflict of interest.

Open Access Dieser Artikel wird unter der Creative Commons Namensnennung 4.0 International Lizenz veröffentlicht, welche die Nutzung, Vervielfältigung, Bearbeitung, Verbreitung und Wiedergabe in jeglichem Medium und Format erlaubt, sofern Sie den/die ursprünglichen Autor(en) und die Quelle ordnungsgemäß nennen, einen Link zur Creative Commons Lizenz beifügen und angeben, ob Änderungen vorgenommen wurden. Die in diesem Artikel enthaltenen Bilder und sonstiges Drittmaterial unterliegen ebenfalls der genannten Creative Commons Lizenz, sofern sich aus der Abbildungslegende nichts anderes ergibt. Sofern das betreffende Material nicht unter der genannten Creative Commons Lizenz steht und die betreffende Handlung nicht nach gesetzlichen Vorschriften erlaubt ist, ist für die oben aufgeführten Weiterverwendungen des Materials die Einwilligung des jeweiligen Rechteinhabers einzuholen. Weitere Details zur Lizenz entnehmen Sie bitte der Lizenzinformation aufhttp://creativecommons. org/licenses/by/4.0/deed.de.

\section{References}

Anderson GL, Jones F (2000) Knowledge Generation in Educational Administration from the Inside Out: The Promise and Perils of Site-Based Administrator Research. Educ Adminis Quarterly 36(3):428-464. https://doi.org/10.1177/00131610021969056

Argyris C, Schön D (1974) Theory in practice: Increasing professional effectiveness. Jossey-Bass, San Francisco, CA

Baron G, Taylor W (eds) (1969) Educational administration and the social sciences. The Athlone Press, London

Bastow S, Dunleavy P, Tinkler J (2014) The impact of the social sciences: How academics and their research make an impact. SAGE, London

Bombaci SP, Farr CM, Gallo HT, Mangan AM, Stinson LT, Kaushik M, Pejchar L (2016) Using Twitter to communicate conservation science from a professional conference. Conserv Biol 30(1):216225. https://doi.org/10.1111/cobi.12570

Budge K, Lemon N, McPherson M (2016) Academics who tweet: "messy" identities in academia. J App Res Higher Educ 8(2):210221. https://doi.org/10.1108/JARHE-11-2014-0114

Cabrera M, Lloret N (2017) Digital tools for academic branding and self-promotion. IGI Global, Hershey, PA

Carrigan M (2016) Social media for academics. SAGE, London

Cho V (2016) Administrators' professional learning via Twitter: The dissonance between beliefs and actions. J Educ Adminis 54(3):340-356. https://doi.org/10.1108/JEA-03-2015-0024

Daly AJ (ed) (2010) Social network theory and educational change. Harvard Education Press, Cambridge, MA

Doyle J, Cuthill M (2015) Does 'get visible or vanish' herald the end of 'publish or perish'? Higher Educ Res Develop 34(3):671-674. https://doi.org/10.1080/07294360.2015.1025467

Eacott S (2017) School leadership and the cult of the guru: the neoTaylorism of Hattie. School Leadership Manag 37(4):413-426. https://doi.org/10.1080/13632434.2017.1327428

Eacott S (2018) Beyond leadership: a relational approach to organizational theory in education. Springer, Singapore

Eacott S (2019) Ranting, raving and complaining: reflections on working against orthodoxy. Int J Leadership Educ 22(6):774-782. https ://doi.org/10.1080/13603124.2018.1492025 
Eacott S (2020) How not to be seduced by common-sense. In: Brooks JS, Heffernan A (eds.), The school leadership survival guide: What to do when things go wrong, how to learn from mistakes, and why you should prepare for the worst (pp. 395-407): Information Age Publishing.

English FW (2006) The unintended consequences of a standardised knowledge base in advancing educational leadership preparation. Educ Adminis Quarterly 42(3):461-472. https://doi. org/10.1177/0013161X06289675

Eysenbach G (2011) Can tweets predict citations? Metrics of social impact based on Twitter and correlation with traditional metrics of scientific impact. J Med Internet Res 13(4):e123. https://doi. org/10.2196/jmir.2012

Fister I, Fister I, Perc M (2016) Toward the discovery of citation cartels in citation networks. Front Phys. https://doi.org/10.3389/ fphy.2016.00049

Giles DC (2002) Parasocial interaction: a review of the literature and a model for future research. Media Psychol 4(3):279-305. https ://doi.org/10.1207/S1532785XMEP0403_04

Gorard S (2005) Current contexts for research in educational leadership and management. Educ Manag Adminis Leadership 33(2):155164. https://doi.org/10.1177/1741143205051050

Gunter HM, Mills C (2017) Consultants and consultancy: the case of education. Springer, Singapore

Hattie JAC (2017) Educators are not uncritical believers of a cult figure. School Leadership Manag 37(4):427-430. https://doi. org/10.1080/13632434.2017.1343655

Hills J (1965) Educational administration: a field in transition. Educ Adminis Quarterly 1(1):58-66. https://doi.org/10.1177/00131 $61 \times 6500100108$

Horton D, Wohl RR (1956) Mass communication and para-social interaction. Psychiatry 19(3):215-229. https://doi.org/10.1080/00332 747.1956.11023049

Howell DC (1988) Statistical methods in human sciences. Wadsworth, New York, NY

Immegart GL (1990) What is truly missing in advanced preparation in educational administration? J Educ Adminis 28(3):5-13

Jefferis T, Bisschoff T (2017) The importance of Twitter in the professional development of digitally-engaged head teachers. Int Stud Educ Adminis 45(2):43-72

Leys C, Ley C, Klein O, Bernard P, Licata L (2013) Detecting outliers: Do not use standard deviation around the mean, use absolute deviation around the median. J Exp Soc Psychol 49(4):764-766. https://doi.org/10.1016/j.jesp.2013.03.013
Marwick AE (2015) Instafame: Luxury selfies in the attention economy. Public Culture. https://doi.org/10.1215/08992363-2798379

Merton RK (1968) The Matthew effect in science. Science 159(3810):56-63. https://doi.org/10.1126/science.159.3810.56

Ortega JL (2017) The presence of academic journals on Twitter and its relationship with dissemination (tweets) and research impact (citations). Aslib J Inform Manag 69(6):674-687. https://doi. org/10.1108/AJIM-02-2017-0055

Pearce KE (2015) Counting to nowhere: social media adoption and use as an opportunity for public scholarship and engagement. Social Media Soc. https://doi.org/10.1177/2056305115578672

Perc M (2014) The Matthew effect in empirical data. J Royal Soc Interface 11(98)

Schnitzler K, Davies N, Ross F, Harris R (2016) Using TwitterTM to drive research impact: A discussion of strategies, opportunities and challenges. Int J Nurs Stud 59:15-26. https://doi. org/10.1016/j.ijnurstu.2016.02.004

Thoma B (2015) Personal reflections on exploring social media in medicine. Int Rev Psychiatry 27(2):161-166. https://doi. org/10.3109/09540261.2015.1005058

Thomson P (2019) Oh to be in England? The production of an unpublic state system. In: Wilkinson J, Niesche R, Eacott s (eds.), Dismantling public education: Implications for educational leadership, policy, and social justice. London, Routledge

van Krieken R (2019) Celebrity society: The struggle for attention. Routledge, London

Veletsianos G, Kimmons R (2016) Scholars in an increasingly open and digital world: How do education professors and students use Twitter? Internet Higher Educ 30:1-10. https://doi.org/10.1016/j. iheduc.2016.02.002

Waite D (2016) Of charlatans, sorcerers, alchemists, demagogues, profit-mongers, tyrants and kings: educational reform and the death by a thousand cuts. Urban Rev 48(1):123-148. https://doi. org/10.1007/s11256-015-0348-3

Walker WG (1964) Teaching and research in educational administration. J Educ Admin 2(1):9-22. https://doi.org/10.1108/eb009576

Walker WG, Crane AR, Thomas AR (1973) Explorations in educational administration. University of Queensland Press, St Lucia, QLD

Watermeyer R (2015) Lost in the 'third space': the impact of public engagement in higher education on academic identity, research practice and career progression. Eur J Higher Educ 5(3):331-347. https://doi.org/10.1080/21568235.2015.1044546 